\title{
A Barthesian Demythologization of a Colonial Painting
}

\author{
Peter Gonsalves
}

\begin{abstract}
In the year marking the birth centenary of the renowned semiotician Ronald Barthes, the article investigates a painting that was commissioned by the members of the British East India Company and installed in the central hall of their office in London. After establishing its historical context, the text employs Barthesian theory to unravel the cultural, symbolical and hermeneutical myths underpinning the ideology that sustained and promoted the colonial enterprise for more than a century.
\end{abstract}

Keywords: British East India Company, British Empire, China, India, myth, mythology, post colonialism, Ronald Barthes

\section{Introduction}

Every work of art conceals a story. At times, the truth behind a story. Some are often ideologies in disguise. A historical approach to the study of art is therefore indispensable, and certainly more intriguing from a semiotic perspective.

In this article we present the historical impact of British colonial trade on the Indian economy that led to the unveiling of a certain painting exactly 178 years after the English set foot on Indian soil. We then analyze the painting itself by employing the structural and post-structural semiotics of Roland Barthes (1915-1980) whose birth centenary we celebrate this year. In doing so, we hope to demonstrate the continuous relevance of his thought, not merely to critique trends in postmodern culture, but to unravel the significance of events that even preceded his birth.

\section{Some History}

Ancient history reveals active trade relationships between India and Mediterranean countries such as Rome and Greece. Some first century authors speak of India in great detail: Pliny's Natural History (c. 50-60 AD), an unknown merchant's Periplus Maris Erythraea (c. 60 AD) and Ptolemy's Geography (c. 150 AD). Historic examples of visitors to India are: Alexander the Great, who in 326 BC stopped short of entering India on the banks of the river Ganges; Thomas and Bartholomew, the Apostles of Jesus Christ, who are said to have visited Southern and Western India around 46 AD; Mohammed Bin Qasim, who conquered the South Eastern part of Sindh in 711; and Ghengis Khan, who invaded Punjab in 1221. One historical figure, however, did not make it. Christopher Columbus, the son of a weaver, set sail for India by a westerly route and "discovered" the Americas instead (Halsall, 2000).

The secret of India's perceived success was the basis of her economy, which lay in village communities. In 1830, Sir Charles Metcalfe, an English official, described India's villages as:

\footnotetext{
little republics having nearly everything they want within themselves; and almost independent of foreign relations. They seem to last where nothing else lasts. This union of the village communities, each one forming a separate little state in itself $[\ldots]$ is in a high degree conducive to their happiness, and to the enjoyment of a great portion of freedom and independence (Nehru 2004, p. 329).
}

However, variations in world markets and the new capitalism were poised to destroy the self-sufficiency of the Indian village system forever. The arrival of the British was to give 
rise to unprecedented changes. India had been conquered before. But the invader always settled within her territory, blended with her culture, intermarried and made himself a part of her life.

\begin{abstract}
She had never lost her independence, never been enslaved. That is to say, she had never been drawn into a political and economic system whose centre of gravity lay outside her soil, never been subjected to a ruling class which was, and which remained, permanently alien in origin and character. (Nehru, 2004, p. 328)
\end{abstract}

The effects of British imperialism gradually disintegrated India's economic and structural foundations. It began on December 31, 1599. The British East India Company was formed by the Royal Charter of Elizabeth I as a "joint-stock company" with a twenty-one year monopoly on all trade in the East Indies on the authority of the British Crown (Robins, 2006). In 1615 a commercial treaty was established between James I and Emperor Jahangir (who ruled over most of Hindustan ${ }^{1}$ along with Afghanistan). The treaty gave the Company exclusive rights to reside and build "factories" in the subcontinent. Then he added these fatal words: "I have commanded all my governors and captains to give them [the English] freedom answerable to their own desires; to sell, buy, and to transport into their country at their pleasure" (Robinson, 1904-6, pp. 333). In return, and as a sign of friendship, he appealed to his Majesty James I, to command his merchants to bring in ship loads of "all sorts of rarities and rich goods fit for my palace" (Robinson, p 334).

Under such lavish patronage the Company spread itself throughout the subcontinent so rapidly that by 1647 , it had twenty-three factories, some of them in places as dispersed as Calcutta, Surat, Madras and Bombay. The chief businesses were exports in cotton, silk, indigo, saltpeter and tea. Around 1670, King Charles II gave the Company further power "to autonomous territorial acquisitions, to mint money, to command fortresses and troops and form alliances, to make war and peace, and to exercise both civil and criminal jurisdiction over the acquired areas" (Slatyer, 2015, p. 75). In 1680, the Company set up its own military to safeguard its interests against European competitors and hostile native rulers. Its army was drawn from the local Indian population. Nine years later, the British East India Company was transformed from a commercial trading venture to a "nation" in the Indian mainland, which independently ruled and administered the vast presidencies of Bengal, Madras and Bombay with formidable military strength.

The Company's aggressive commercial activity had repercussions not merely in India but in England as well. Muslin and calico from India were exported in large quantities thanks to their beauty and cheapness. They became part of high fashion for ladies' and children's wear, as well as for drapery and furniture (Thomas, 1963). ${ }^{2}$ This liberal import of Indian textiles that began to ruin the ancient woolen production of England led to an outcry against the admission of Indian goods (Suchak, 1999). London's silk weavers rioted by storming East India House at Leadenhall Street, London. In 1700, prohibitory acts were passed by the British parliament. They prevented the entry of all dyed and printed cloth from India while restricting the introduction of Indian silk for domestic use under a penalty of $£ 200$ on the wearer or seller. In contravention of the ban and at the risk of being fined, upper class women continued to wear Indian cotton (Mukund, 1992; Harzinski, 2005).

\footnotetext{
${ }^{1}$ India was called 'Hindustan', 'place or country of the Hindus' by Arab traders in the 6th century.

2 "On a sudden we saw all our women, rich and poor, cloath'd in Callico, printed and painted; the gayer and the more tawdry the better. [...] It crept into our houses, our closets and bedchambers; curtains, cushions, chairs, and at last beds themselves were nothing but Callicoes or Indian stuffs. In short, almost everything that used to be made of wool or silk, relating either to dress of the women or the furniture of our houses, was supplied by the Indian trade" (Thomas, 1963, p.30).
} 
In 1717, the Indian Emperor Furrukhsiyar, exempted the Company from payment of customs duties in Bengal and confirmed its presence in India (Cavaliero, 2002). Nineteen years later the Manchester Act forbade all Indian cloth goods inside England, so that Lancashire now had the monopoly on printing, manufacturing, and the sale of cotton cloth. This, however, did not prevent the import of raw cotton from India to feed British mills (Harzinski, 2005). ${ }^{3}$ The imperial machine was now at full throttle. Nick Robins, author of The Corporation That Changed the World: How the East India Company Shaped the Modern Multinational, mentions the high points that accelerated the "loot":

\begin{abstract}
The situation changed dramatically in the middle of the 18th century, as the Company's officials took advantage of the decline of the Mughal Empire and began to acquire the hinterland beyond its vulnerable coastal trading posts. Territorial control enabled the Company both to manipulate the terms of trade in its favour and gouge taxes from the lands it ruled. Within a few years of Clive's freak victory over the Nawab of Bengal at Plassey in 1757, the Company had managed to halt the export of bullion eastwards, creating what has poetically been called the 'unrequited trade' - using the East's own resources to pay for exports back to Europe. (Robins, 2003)
\end{abstract}

The plunder of India through the Company's unilateralism so increased the craving for absolute power that it started to spread its tentacles of influence in government circles as well. Many Company officials began to hold seats in Parliament or to procure seats for family members. The situation induced a forthright parliamentarian Horace Walpole to say, "What is England now? A sink of Indian wealth, filled by nabobs" (Robins, 2003). ${ }^{5}$

Even China was not spared. The Company exported opium to China to cover England's purchase of China's tea and porcelain - despite the fact that the Qing dynasty had outlawed opium (Janin, 1999). ${ }^{6}$ The commercial domination of Asia was now complete, and the directors of the Company required a symbol to flaunt it. In 1778 they installed an extravagant painting executed by an Italian artist, Spiridione Roma, entitled, The East Offering Her Riches to Britannia (Figure 1). Ten feet long and eight feet wide, it was fixed to the ceiling of the East India Company's revenue committee room, where the directors monitored the flow of profit and loss (Robins, 2006).

By 1780 the Company seemed invincible in England as well. About a tenth of the seats in Parliament were held by its own officials. Only in 1784 with the approval of the "India Act" was the executive management of the Company's Indian affairs finally transferred to a Board of Control answerable to British Parliament. Effectively, this meant that for the next seventy years the British Government would have the power to decide how the Company's booty from India would be shared (Keay, 1994).

Horace Wilson's History of British India (1826) confirmed that the mills of Manchester flourished because "they were created by the sacrifice of Indian manufacturers" (Chomsky, 1993, p. 14). Montgomery Martin testified before the British Parliamentary Committee in 1840 that an outrage had been committed "by reason of the outcry for free trade on the part of England without permitting India a free trade herself" (Clairmonte, 1960, pp. 86-87). With statistics of the years 1815 to 1832, he demonstrated how prohibitive duties on textile and other articles from India to Britain rose from $10 \%$ to

\footnotetext{
${ }^{3}$ English novels of this period also speak of cloth thefts. See, for instance, Daniel Defoe's Moll Flanders (1722).

${ }^{4}$ The word 'loot' originated in 1788 and is taken from Hindi which means: "booty, stolen property". Cf http://www.etymonline.com/

${ }^{5}$ Nabob is a corruption of the Urdu-Hindi word 'nawab'. Nawabs were provincial governors of the Moghul Empire. The term used by Englishmen of this period carried with it the pejorative meaning of a corrupt officer.

${ }^{6}$ In 1839 , the confiscation of 20,000 chests of opium by the Chinese authorities at Canton led Britain to attack China in the First Opium War (Janin, 1999, p. 28).
} 
$1,000 \%$ (Clairmonte). ${ }^{7}$ In 1853, a columnist writing for the New York Tribune admitted: "[T]he misery inflicted by the British on Hindostan is of an essentially different and infinitely more intensive kind than all of Hindostan had to suffer before" (Robins, 2006, p. 160). The writer was a certain Karl Marx. Nothing could have epitomized the loot better than Roma's romanticized artwork - the object of the semiotic study to follow.

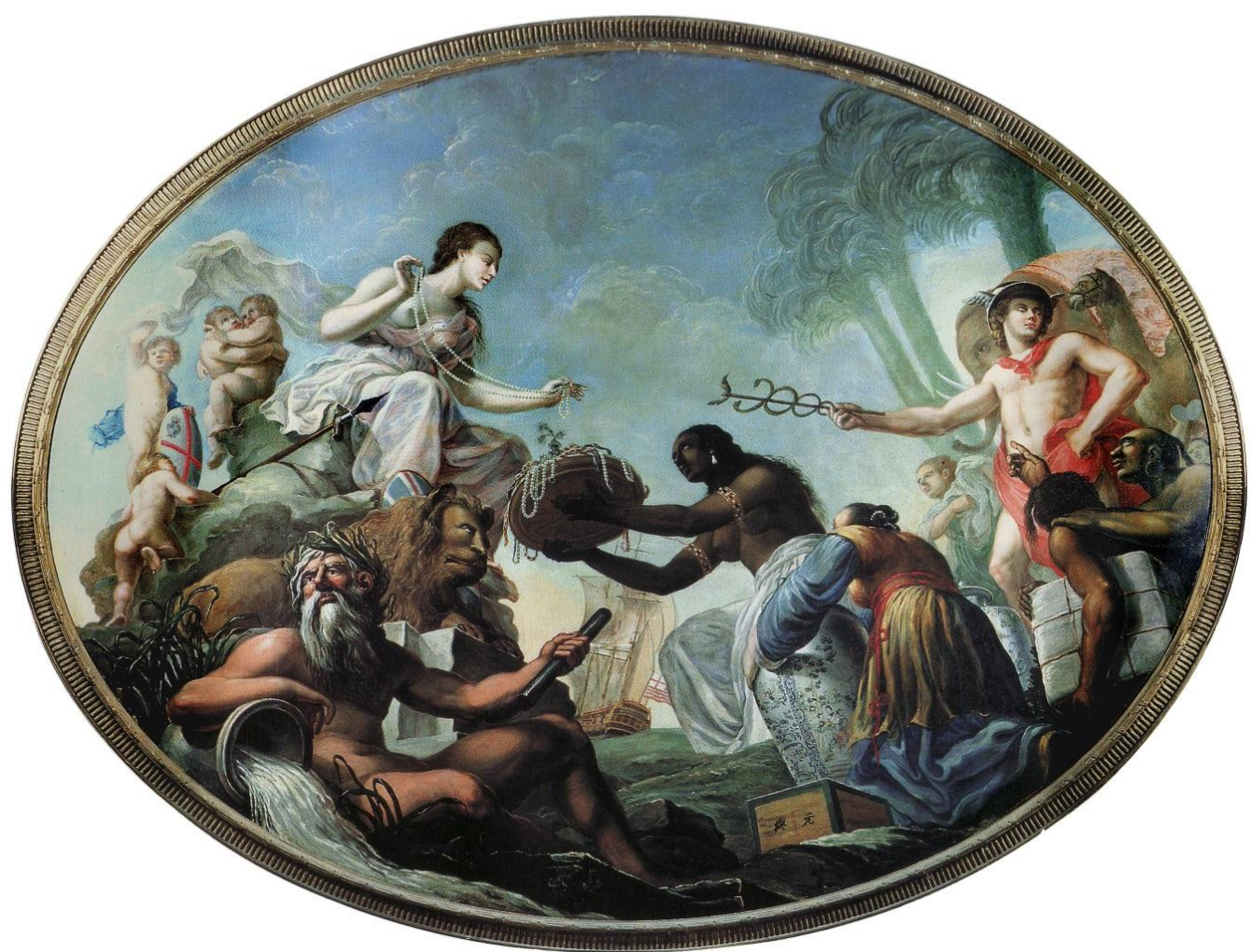

Figure 1. Spiridione Roma's “The East Offering Her Riches to Britannia” (1778)*

\section{A Barthesian Analysis}

Semiotics is commonly defined as the science of signs, especially in a human cultural context; "how they work and the way we use them" (Fiske \& Hartley, 1985, p. 37). Ronald Barthes, a prominent French cultural analyst and semiotician, developed the science to the point of respected scholarship. ${ }^{8}$ He looked at cultural phenomena as language systems, and thereby followed in the linguistic structuralist tradition of Ferdinand de Saussure (1916). He transcends Saussure, however, in his application of structuralism to everyday, non-linguistic realities as wide as literature, advertisements, photography, fashion, films, music and even notions of the self, of history, and of nature.

\footnotetext{
${ }^{7}$ William Digby, author of the 1902 study Prosperous British India: A Revelation from Official Records argued that "before the stream of loot began to flow to England, the industries of our country were at a low level. Lancashire spinning and weaving were on a par with the corresponding industry in India so far as machinery was concerned; but the skill which had made Indian cottons a marvel of manufacture was wholly wanting in any of the Western nations [...]" (Clairmonte, 1960, pp. 73-74).

* Photograph taken by the author at the Durbar Court, Foreign and Commonwealth Office, London, 2012.

${ }^{8}$ Ronald Barthes was a "formidable figure on the cultural and critical scene: a powerful presence, a commentator on everything under the sun, and a distinguished eminence of an avant-garde that had radically transformed the humanities in general and literary studies in particular." (Culler, 2002, p. viii).
} 
He once admitted: "What has fascinated me all my life is the way people make their world intelligible" (Barthes, 1985, p.15). He shifted Saussure's emphasis from the semiotics of language to the exploration of semiotics as language, enabling it to probe and unravel significance in all media of human communication. In this sense, he is one of the initiators of the post-structuralist school (Chandler, 2007).

\subsection{The Orders of Signification}

Building on the foundations of the Saussurean model of the linguistic sign, and the orders of signification of Louis Hjelmslev (1961), Barthes recognizes that every word is a composite of signifier and a signified. The signifier is the pattern in which the sign appears - for example, the letters of the alphabet that form the word. The signified is the concept the pattern signifies. Thus the letters ' $h$ ', ' $i$ ', 'g' and ' $h$ ', together form a signifier 'high', that means: a position on a vertical scale that is relatively elevated. It contrasts with another signifier, 'low', that signifies a position that is relatively at the bottom of a vertical scale. Thus, when the words 'high' or 'low' are written or spoken, they are signs that mean what they indicate, in opposition to one another. Their significance is the relation between the signifier and the signified. This pure equation between signifier (the word), signified (the concept) and the resultant significance (meaning) is called by structuralists like Hjelmslev and Barthes, denotation - the first level of signification. All words, numbers, or the dots and dashes of Morse code are examples of signs with denotation.

We need to be aware that although the signifier objectively points to the signified as a full-fledged sign, the relationship between signifier and signified is relatively arbitrary in language. This accounts for the diversity of signs (words) that point to the same signified by means of other signifiers (such as words for 'high' and 'low' in other languages: 'alto' and 'basso' in Italian; 'upar' and 'niche' in Hindi; 'wysoki' and 'niski' in Polish, and so on). All one needs is conventional approval to sanction the existence of such signs, which is why linguistic signs are also called conventional signs. Shakespeare underscores the arbitrary relationship between a rose and the word 'rose' in his celebrated quip: "What's in a name? That which we call a rose by any other name would smell as sweet." "9

Would the literal, denotative correspondence between signifier and signified that is common to language exist even if the signifier were a painting, a sign that is predominantly iconic? Among other aspects, signification in pictures is the result of an addition of more signifieds to denotative signs which do not exist as separate entities but always within a sign system. Thus denotative signs take on determinate connotations when the sign of the first order becomes a signifier for another signified, as shown in Figure 2. Similarly, within an aesthetic or artistic system, the figures in a painting are more than mere denotative signs, because no two artists will paint a given theme in the same manner. Each will make selections based on his or her subjective ability, imagination, preferences and values. For instance, Roma's artwork under study reveals his biases in the way he has positioned the women along an oblique imaginary line from high to low. Thus, Britannia is high up to the left while the women of the "East" are lower down to the right of the painting. Roma has chosen to frame his subjects within a system in which the viewer is led to see and understand only through eco-political comparisons. One recognizes who is rich and powerful and who is not, because the composition itself is inherently semanticized. Roma gives the painting dramatic effect by

\footnotetext{
${ }^{9}$ Shakespeare, Romeo and Juliet, Act 2, Scene 2.
} 


\section{P. Gonsalves}

raising ordinary denotative signs to the level of connotations. The eco-political values added to the pure denotations of 'high' and 'low' can now connote 'superiority' and 'inferiority', 'domination' and 'servitude', 'luxury' and 'penury'. Britannia's exalted place with respect to the subservience of the East is not arbitrary, nor interchangeable, nor neutral, nor devoid of metaphor. It is pregnant with signifieds of the second order of signification.

How does this happen? How do denotations become connotations permeated with meanings? Barthes points to mythology or what is commonly called "ideology" - the third order of signification. ${ }^{10}$ The connotative signs used by the artist are the result of shared inter-subjectivity among members of his culture that is linked to judgements, attitudes, emotions, values and beliefs.

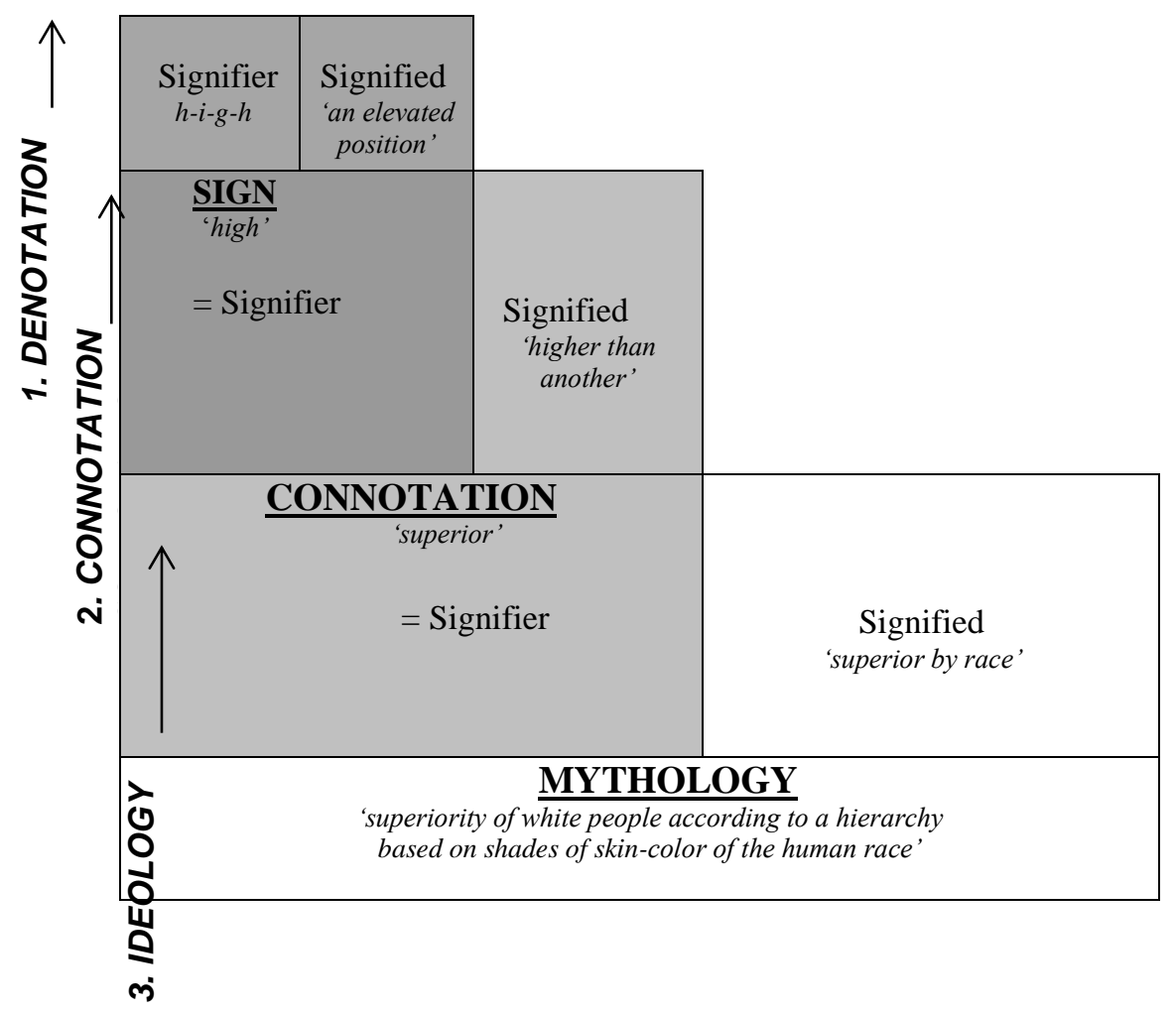

Figure 2. Barthes' Three Levels of Signification

Through the exchange of cultural and historical myths, bonds are strengthened and a culturally ordered system is formed. Here signs reflect socially and politically dominant concepts that underpin particular worldviews. They serve the ideological function of naturalization. Myths therefore surpass their connotative function. They now naturalize connotative myths by turning them into mainstream attitudes, behaviors, values and beliefs that are an inherent part of cultural and historical ways of interpreting the world. They define what people of a culture consider normal, self-evident, a matter of common sense. They control social behavior because they are unquestionably accepted as "what goes without saying" (Barthes, 1973, p. 140).

\footnotetext{
${ }^{10}$ While Barthes argues that the combination of denotation and connotation produces ideology, the choice to describe it as the third order of signification is not his (See Fiske and Hartley, 1978).
} 
In the painting under study, the choice that motivates Roma to place his figures along an oblique line is informed precisely by cultural mythologies. They include a certain knowledge of the historical context, both of which are inextricably linked to the ideological baggage he lives off. At the time he executes the painting for the East India Company, he is aware that Britannia, to whom the Company belongs, is the imperial power under which the subjugated India and China have no option but to bow in obeisance. This submissive posturing justifies the vertical arrangement of figures and naturalizes the ideology that determines who should be high and low. Furthermore, their placement in the painting also reinforces the established geo-political position of the countries. Britannia to the North West of the frame and India and China to the South East replicate the cartographical coordinates first followed by Gerardus Mercator in the mid sixteenth century. Any attempt to reverse these accepted myths woven into the general layout of the painting would violate common sense perceptions and would even be considered odd, if not anarchistic or seditious. Thus, by inserting his painting within the mythological parameters acceptable to members of the East India Company, Roma more than satisfies his employers. He regales them with a triumphalist icon, presumably in the hope that they reward him generously for the compliment.

\subsection{Variability of Readings and the Semantic Codes}

If signs, whether verbal or non-verbal, do not exist in isolation, if they are saturated with denoted and connoted significance, if they are tied down to cultural or mythological baggage, how are they to be read?

While denotation is the natural, objective level at which certain signs (like the Morse code) are understood, most signs require inputs from culture to help readers grasp their meaning. As Barthes (1977, p. 28) states: "Signification [...] is a dialectical movement which resolves the contradiction between cultural and natural man". Any reader of any text constantly discovers meanings by negotiating between the connoted and the denoted, the cultural and the natural, the subjective and the objective, the analogical and the historical. To be human is to be caught up in the vortex of sign systems in which the act of making meaning is the only way to be and to know. Cultural semiotics is thus an ontological necessity.

\footnotetext{
We know now that a text is not a line of words releasing a single 'theological' meaning (the 'message' of the Author-God) but a multi-dimensional space in which a variety of writings, none of them original, blend and clash. The text is a tissue of quotations drawn from the innumerable centres of culture (Barthes, 1977, p. 146).
}

Knowledge of cultural codes is of prime importance in deciphering significance and acting purposefully. A reading of these codes differs according to individuals because each individual taps into the codes from the culture he/she is familiar with. Since each person has a unique history and experience of culture, no two individuals read a text in exactly the same manner.

In his work $S / Z$, published in 1970, Barthes shows how readers of a text (verbal or non-verbal) can be methodically guided in the search for meaning despite the "galaxy of signifiers" that confronts them. He proposes the use of five basic codes for determining various kinds of significance. They are presented here with no proper order of priority.

a. The proairetic code deals with the narrative action of the text. It refers to actions that are performed, identified, recorded and read as a story in the course of its 
unfolding. It is empirically based and indicates the plurality of meanings entangled in the actions as they emerge through the narrative (Barthes, 1985).

b. The semic code forms part of the text's connotations, or stereotypes pertaining specially to the person mentioned in the text. It "gathers together signifieds which are more or less psychological, atmospheric, pertaining to character" (Barthes, 1985, p. 74).

c. The symbolic code allows us to recognize signs in the second order of signification. This is the "place for multivalence" that permits entry into a text from different points (Barthes, 1974, p. 19). It is the most complex of codes because it is metaphorical; "its logic differs radically from the logic of reasoning or of experience. It is defined, like the logic of dreams, by elements of intemporality, substitution, and reversibility" (Barthes, 1985, p. 74).

d. The cultural code identifies sets of knowledge within the text. Unlike the symbolic code that is chaotic and circuitous, it can be formally laid out into subject groups such as history, medicine, literature, psychology and economics. This code incorporates the intention of the author or artist. A reader who is conversant with the subject being treated by the author will be able to identify significations that are likely to escape the attention of the common reader or one who is specialized in other fields. The point that is being made by this code is not the "correctness" of the text but how it signifies (Barthes, 1985).

e. The hermeneutic code is the one that conceals enigmas and truths still to be discovered. Through it the reader addresses mysteries of meaning hidden in the text. All the reader is asked to do is to "list the various (formal) terms by which an enigma can be distinguished, suggested, formulated, held in suspense, and finally disclosed" (Barthes, 1974, p. 19).

Barthes is aware that these codes are not universally applicable. Not all texts are susceptible to penetration by all of them. He distinguishes between classic and modern texts as examples which he calls readerly and writerly texts respectively. In a classic text, which has strict sequential elements, the presence of the proairetic and hermeneutic codes dominate. These two codes function in a linear, logico-temporal fashion and thereby sustain the strong narrative of the text that engages the reader in the passive activity of consuming the meaning of what is written (readerly texts). Texts that are modern are nonsequential. Their execution in an abstract, non-narrative style increases their dependence on semic, symbolic and cultural codes - three codes that function non-linearly, outside the constraints of time. The text can be re-written even as the reader reads; their meanings are actively produced by the reader (writerly texts). Metaphorically speaking, the writerly text is like a grand piazza "open" to visitors who can enter and exit from different points. It involves each reader in the construction and interpretation of the text. The readerly text instead is a one-way street that is "closed" to alternative interpretations. Having complete control over the structure and meaning of a text, it has only one entrance and one exit.

For Barthes, the ideal text is one that is reversible, non-linear and open to a number of interpretations, allowing the reader the freedom of analysis and the joy of participating in the creative process. It is somewhat like modern art or trick paintings that enable the reader to discover meaning in the course of whichever direction he/she wishes to proceed. 
The painting The East Offering Her Riches to Britannia, is largely readerly, although we can trace some writerly elements as well. Though not artistically deserving of merit, ${ }^{11}$ it is a rich allegorical text in content and form. Our process of decoding the painting will begin with the reading of the human figures. The first two letters of each code in parenthesis will indicate the specific code used. Table 1 will serve as a guide throughout the analysis in which the contents of the painting and its aesthetic form will be discussed.

Table 1. Barthes's Five Semantic Codes

\begin{tabular}{|l|l|l|}
\hline Abbreviation & Name of code & Purpose of code \\
\hline PR & Proairetic code & Indicates the action and narration in the text \\
\hline SE & Semic code & Pertains to significations and character of person \\
\hline SY & Symbolic Code & Points to mythic or metaphoric sign systems \\
\hline CU & Cultural code & Identifies disciplines of knowledge referred to \\
\hline HE & Hermeneutic code & Addresses enigmas, doubts or mysteries in a text \\
\hline
\end{tabular}

\subsubsection{Content}

A fair skinned lady seated high on a rock, to the left of center, is the focus of the whole painting. The figures on the right gravitate towards her. (PR) She is Britannia, the original Latin name the Romans had given the British Isles around $55 \mathrm{BC}(\mathrm{CU})$. The personification of England through early paintings show her draped in white with her right breast exposed, just as in Spiridione's work (CU). This mode of emphasizing her beauty symbolizes national well-being and happiness (SY). She wears white except for the light touches of red, and blue - colors used in the flag ${ }^{12}$ of the East India Company (SY). She sits on a rock, a symbol of stability on which the Company is founded (SE/SY). The shield with a red St George's cross on a light blue background at her right foot, covered partly by the lion, and the spear resting on the rock - all these form part of her traditional ensign (CU). Roma's Britannia leans forward as she holds a necklace in her delicate white hands. Her gaze surveys with interest the abundance of gifts being offered (PR, SE). The casket overflowing with jewelry is held out by the dark, muscular hands of a full-bodied woman who represents India (SY). Her eyes are reverently raised to behold Britannia before whom she genuflects in obeisance as if to her queen. Her naked torso leans forward in reverence (PR) resembling a ritualized darshan: in the very act of offering, she herself is blessed (SE). In attendance behind her with her head bowed low is a heavily clothed lady. She kneels patiently between two porcelain jars and a wooden box of tea at her left knee (PR). The dress, the text on the box and the design on the jars tell us that the lady represents China (CU). Like India, her posture is also one of servile veneration of Britannia (SE).

Following China, two dark-skinned men await their turn. The tuft of hair on their heads indicates that they are Hindus from India (CU). Their muscular arms reveal they are laborers or "coolies" - a popular colonial stereotype of cheap Indian labor (CU). One of them carries bales of cotton (PR), indicating the type of commerce that the East India Company was engaged in (CU). At the time of the painting, the Company imported raw

\footnotetext{
${ }^{11}$ It was described by Edward Edwards in Anecdotes of Painters, as "a work too feeble to confer any credit either on the artist or his employers". Quoted by Robins (2006, p.1).

${ }^{12}$ From 1707 to approximately 1800, the Honourable East India Company ensign incorporated the British Union flag at its top left corner. The Union flag had the St. George Cross at its centre. It was white, red and blue.
} 
cotton into England to feed its new textile industry in Lancashire (CU). The second laborer's left arm rests firmly on the shoulder of his companion, as his index finger points to Britannia (PR) - the final destination of their long and laborious voyage (SE). He encourages his companion, bent with the weight of the load (PR), to understand the ultimate significance of their toil: pleasuring goddess Britannia (SE).

Next, we decipher the presence of the two white male figures. To the right of the painting is Mercury, the god of trade, profit, and commerce. His helmet, staff, and cape are the unmistakable symbols of his identity $(\mathrm{CU})$. His pose suggests that he is the stern overseer who directs the procession of gift-bearers. The right arm carrying the caduceus ${ }^{13}$ points to the goddess (PR, SY). The bent knee and his left arm akimbo tell us that he is at ease, fully conscious of his self-importance (SE). His leftward gaze stretches beyond the confines of the painting (PR), indicating that the procession is long and that Britannia has many more undiscovered treasures in store (SY, CU, HE). The choice of Mercury, however, is an enigma. Traditionally, Mercury is considered to be the "guide of the dead and protector of merchants, shepherds, gamblers, liars, and thieves" (Hornblower 1996, p. 690) (CU). One wonders if the decision to include Mercury was Roma's or that of those who commissioned the painting. Were they aware of the subtle irony that discredited their whole enterprise in the eyes of the morally sensitive viewer? Or was Roma being subtly rebellious? (HE)

The other character is old Father Thames, the naked old man reclining leisurely on the urn that overflows with water (PR). The inclusion of this traditional personification of the river that flows through London (SE, SY) emphasizes its role in the process of unloading goods brought to Britain from India and China before they were transported to Lancashire and Manchester (CU). The playful putti behind Britannia form part of her escort. One of them holds the shield while the others are at play (PR). They are healthy and feel safe under her protective mantle (SE). But they could also be a metonym for the "invisible" protection Britannia enjoys at the hands of the Company (HE, CU).

The lion, the king of animals and a symbol of power, is depicted as the traditional mascot defending Britannia (SY, CU). On the right, behind Mercury, are the elephant and camel, both symbolizing the domesticated and exotic East (SY, CU). The succession of palm trees represents a typical Indian coastline (CU). The high seas divide the two landforms with a ship in full sail at the center of the painting (HE). The cross of St. George and the stripes on its flag fluttering in the wind indicate that it is one of the Company's merchant ships (CU). The resplendent light that surrounds the ship accentuates the pivotal role the Company played in bringing the wealth of the East to enrich Britannia (CU). Its faint presence in the background, as a central and luminous witness, appears to be a tribute to the East India Company, the sine qua non of England's prosperity.

\subsubsection{Aesthetic Form}

The painting also has an underlying sign-system that gives the composition its aesthetical balance. It is oval shaped, signifying circularity, movement and completeness (SY). The left half contrasts with the right through the use of space and color hues. The top left corner of the painting is brighter, with lighter shades of blue, yellow, and pink. ${ }^{14}$ The

\footnotetext{
13 The caduceus is a herald's staff with two entwined snakes. It was Apollo's gift to Hermes, the GrecoRoman counterpart of Mercury.

${ }^{14}$ This brightness that surrounds Britannia in Roma's painting is prophetic. At the height of its power the Empire spanned the whole globe. The sun was always shining on at least one of its numerous colonies, which provoked the popular saying: "The sun never sets on the British Empire."
} 
bottom right half is filled with dark hues and can be considered peripheral (SY). The stark contrast between the two sides of the diagonal split in the frame sums up the colonial ideology: the North West prospers on the "offering" of the South East - a concept that anticipates the notion of the "North-South Divide" (CU) (see Figure 3).

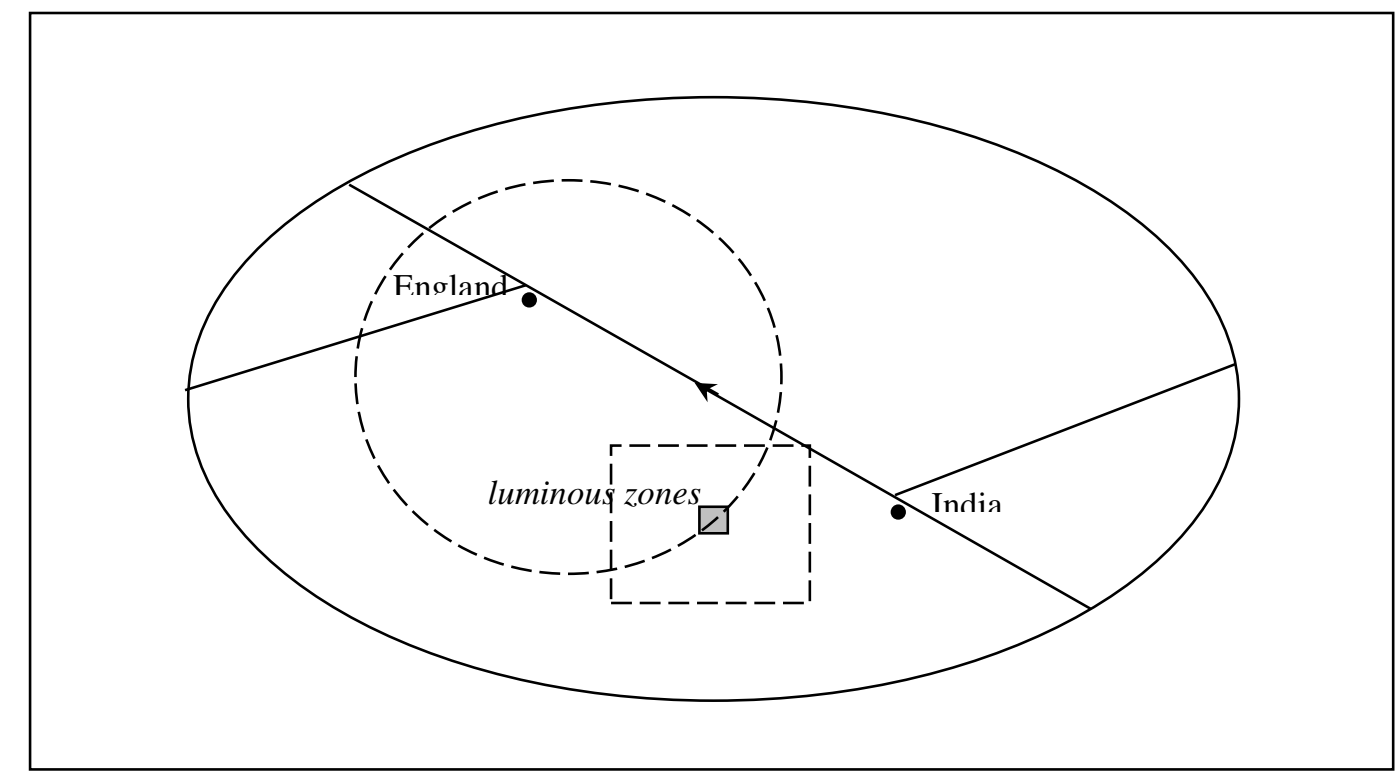

Figure 3. Interplay of Darkness and Light in The East Offering Her Riches to Britannia

Thus the movement of the actors in the narrative is unidirectional, from the point on the lower right to the epicenter on the upper left; from instability, submission, and servility towards stability, pride and prosperity (SY). The figures on the right are on their feet or on their knees in the act of offering their gifts; the figures on the left are passive, sedentary, surveying the gifts received (PR). Although the flow of action from the bottom right to the top left of the painting was the underlying strategy driving British colonialism, Roma's clients, accustomed to reading from the left to the right, would naturally judge the painting from Britannia's point of view: her ability to charm the Eastern races of the earth to the extent of making their many sacrifices seem like their own reward (PR, HE). Through his visual mythology, Roma succeeds in divinizing the ideology of the East India Company in its surge for more power under imperial patronage. The looting of wealth is mythicized, signifying a holy ritual of benevolent obeisance undertaken gratuitously by the East to pamper Britannia's excessive selfindulgence.

\subsection{Structural Relationship of Signs}

We have seen that signs accumulate meaning in relation to other signs within a sign system. Borrowing from Roman Jakobson (1971), Barthes goes a step further to demonstrate how meaning arises from the differences between signifiers, which are of two kinds: syntagmatic and paradigmatic. The differences operate within the structure of a text like two axes (Figure 4). 


\begin{tabular}{|c|c|c|c|}
\hline \multirow{8}{*}{ 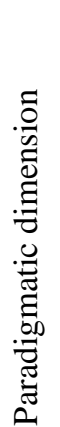 } & \multirow[t]{8}{*}{ 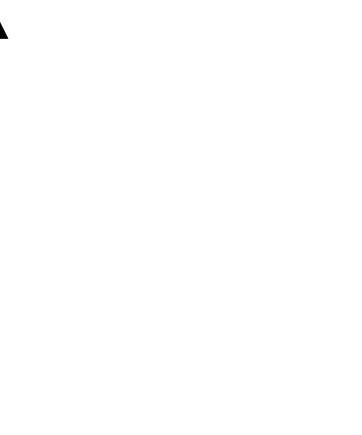 } & Paradigmatic & Syntagmatic \\
\hline & & metaphor & metonym \\
\hline & & selective & combinative \\
\hline & & discontinuous & continuous \\
\hline & & substitution & positioning \\
\hline & & exclusive & inclusive \\
\hline & & this-or-that & this-and-that \\
\hline & & $\begin{array}{l}\text { Example: } \\
\text { shirt or jacket (for } \\
\text { the torso) }\end{array}$ & $\begin{array}{l}\text { Example: } \\
\text { shirt and pant... } \\
\text { jacket and jeans... }\end{array}$ \\
\hline & Syntagmatic dimension & & \\
\hline
\end{tabular}

Figure 4. Two Systems of Signification

The paradigm is the vertical axis that is selective, discontinuous, and associative; the syntagm is the horizontal axis that is combinative and continuous. The paradigm cuts vertically and decisively into a text to identify its underlying content. It contrasts with what is not chosen, with what is absent or could be substituted. A syntagm fits within the horizontally integrative arrangement of a text to identify its surface structure. The paradigm is a metaphoric choice; one sign is associated with another. The syntagm is a metonymic choice; one sign is a part of a whole sign system. The paradigm is an exclusive unit, and therefore discontinuous. The syntagm is an incomplete unit, a piece in a puzzle and therefore continuous (Chandler, 2007). Both paradigms and syntagms form the basic structure of any semiotic system. Against this structural framework, the communicator sets codes to represent concepts and inevitably taps into culture, usually the one most familiar, and draws out the signifiers to articulate the signified (Barthes, 1977, pp. 50-51).

Barthes supplies an example from the "garment system". A person can select clothing signs from three paradigms: upper body garments, lower body garments and footwear. For the first paradigm, one can choose from a set of syntagms or continuous signs like shirts, jackets and sweaters; from the second, pants, jeans, pajamas and shorts; from the third, shoes, sandals and slippers. The paradigmatic elements are such that they cannot be worn at the same time on the same part of the body. One either wears shoes or sandals, but not both at the same time. The syntagmatic dimension instead, is the simultaneous juxtaposition of different elements in a complete ensemble from shirt to shoes. Thus while only one paradigm is chosen for the foot from a variety of others, it is related horizontally as a syntagm (as one in a combined set) with other paradigms that are also chosen. The combination is motivated by culturally accepted rules - shirts with pants and shoes, tee shirts with jeans and sandals. Thus the whole syntagm communicates a cultural message whether as "formal dress" or "casuals" (Barthes, 1990).

How does the interplay of the two axes work in the structure of Spiridione Roma's The East Offering Her Riches to Britannia? We are aware that the artist was commissioned to create a painting that would reveal the exceptional success of the East Indian Company in propelling England to the pinnacle of prosperity. He takes note of the three polarities to be emphasized - England as an invincible power, the East as docile and acquiescent, and the Company as the reason for Britain's affluence. Conscious of the sensibilities of his British sponsors and informed by the stereotypes of their culture, he sets out to select from a variety of possibilities. To represent England, he chooses a 
cultural paradigm already in vogue - the goddess-like figure, Britannia. His paradigmatic choice favors a feminine character rather than a masculine one. He balances this choice with two other female representations for India and China, manifesting his syntagmatic concern for continuity. He introduces the inequality among the characters through a set of discontinuous (paradigmatic) elements like color, clothing, posture, and position. He contrasts their status by playing with binary opposites, such as fair-skinned/dark-skinned, clothed/unclothed, sitting/kneeling, selecting/offering, erect/inclined, high/low. He further emphasizes the contrast of status by representing the attitudes the painting will evoke through another paradigm - animals, not humans or buildings or maps. Once again he studies combinations to provoke the contrast. He does not have to look far for cultural stereotypes: the Lion for Britain (and not the Red Deer, the most common national animal), and the Elephant and Camel for the East (and not the fierce Cobra, ferocious Tiger, or proud Peacock).

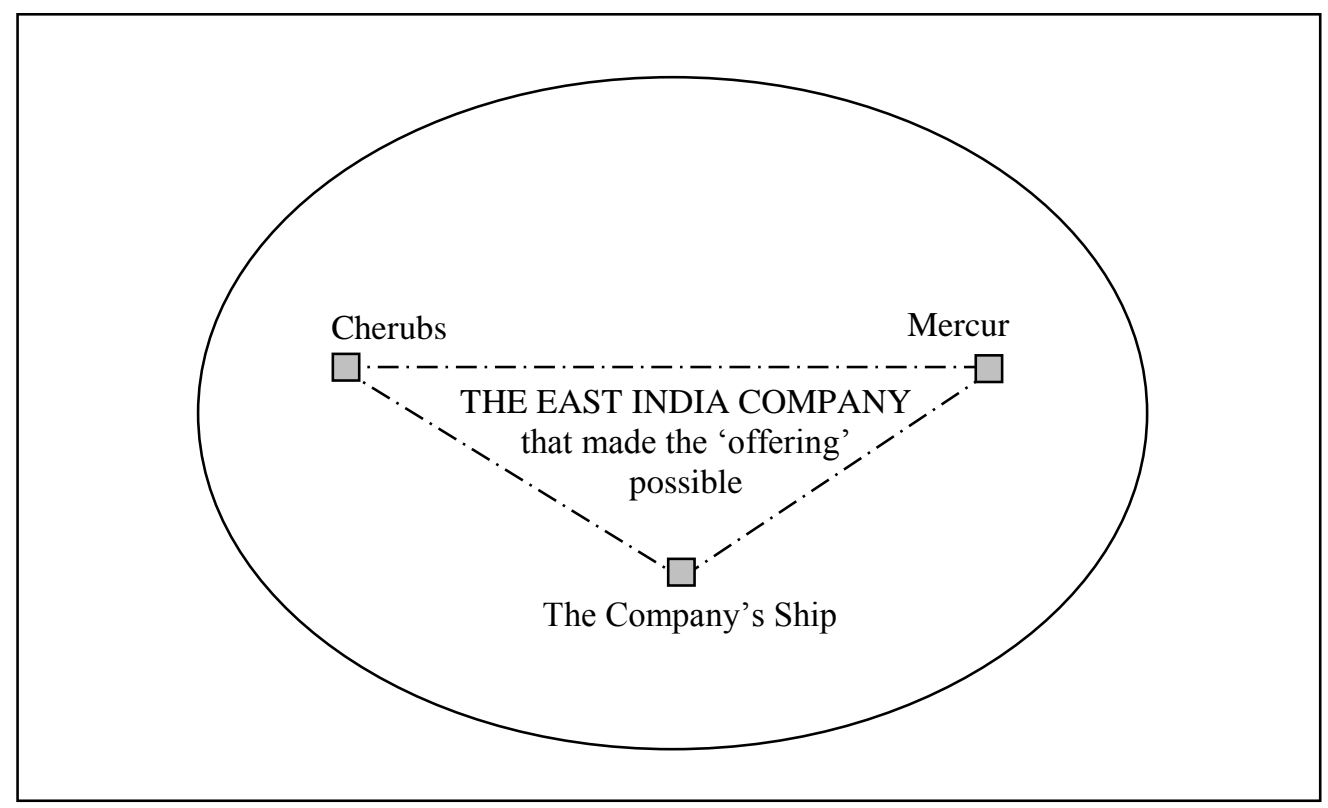

Figure 5. Myths signifying the East India Company in The East Offering Her Riches to Britannia

Finally, Roma subtly exhibits his genius when he decides to compliment the East India Company through the structural relationship of three signs in his painting. He uses a geometrical paradigm, an inverted invisible triangle that spreads throughout the work, such that the indispensable signified is always in view (Figure 5). The syntagmatic signifiers are: Mercury on the right, the cherubs on the left, and the Company's merchant ship at the lower center. Goddess Britannia, Roma seems to say, would not have had the luxury she so comfortably enjoys, if it were not for the loyalty of her humble subjects (the cherubs), their daring conquests of distant lands and peoples (the ship) and the plentiful booty they bring home to replenish British coffers for centuries to come (Mercury).

A comparison with a similar work of art in the same headquarters in London may help us understand an alternative paradigm. A grand chimneypiece executed around 1729 by Dutch sculptor, Michael Rysbrack, presents a different equation. The artist chooses a horizontal linearity by portraying a woman representing Asia offering gifts to a passive Britannia who sits regal and benign. However, both are on equal ground: Asia presents her gift while looking into Britannia's eyes. The reason behind the elimination of the 
distance between high and low that pervades Roma's painting is evident when one examines history. At the time the chimneypiece was executed, Indian cloth was sought after in England, to a point where the weaving associations created a revolt. As we have seen earlier, the scare led to the creation of the Manchester Act of 1736. The chimneypiece is created when the Company based its commerce with India on principles of exchange. ${ }^{15}$ The prevailing ideology looked at India as a fair competitor, which explains its title: Britannia Receiving the Riches of the East.

Roma's Offering belongs to a later date, twenty-one years after the systematic looting of Bengal at the Battle of Plassey. Major-General Robert Clive defeated the Nawab and installed his traitor, Mir Jafar, at a price that was previously agreed upon. In return, Clive siphoned off to England gold and silver worth, in today's terms, £232 million for the company and $£ 22$ million for himself. It was considered the East India Company's "most successful business deal" (Robins, 2006, p. 3). The prevailing ideology justified triumphalism, the end of competitive trade and the glorification of thievery.

\title{
4. Conclusions
}

Roma's painting is an auto-referential readerly text that moves in a unilateral direction allowing the viewer not even an iota of doubt. It was a painting that summed up the Company's ideological propaganda - a cultivated delusion to foster the Englishman's pride in Britain's unrivalled political and economic status; and his faith in the world's first transnational joint-stock company (Bremner, 2005; Robins, 2006). The painting is a perfect example of how connotative myths assimilate raw reality only to naturalize it as "what goes without saying". The distortion of the real makes the lie acceptable by obliterating the sting of inconvenient facts. History and human interaction are rendered natural, excusable and, therefore, palatable to the majority.

Like so many depoliticized bourgeois myths, the painting provides the rationale for clinging on to an ideology of identity and nationhood that legitimizes self-indulgent modes of social, cultural and political behavior. In Barthes own inimitable language, we begin to experience the absence of the very reality we started out explaining:

\begin{abstract}
Semiology has taught us that myth has the task of giving an historical intention a natural justification, and making contingency appear eternal [...]. The world enters language as a dialectical relation between activities, between human actions; it comes out of myth as a harmonious display of essences. A conjuring trick has taken place; it has turned reality inside out, it has emptied it of history and has filled it with nature, it has removed from things their human meaning so as to make them signify a human insignificance. The function of myth is to empty reality: it is, literally, a ceaseless flowing out, a haemorrhage, or perhaps an evaporation, in short, a perceptible absence (Barthes, 1973, p. 155)
\end{abstract}

Thus, with a mythology to soothe the conscience of the English by keeping reality out of sight and mind, the Company in India extended its 'real' control over the colony long enough to guarantee the prolongation of British imperialism well into the first half of the twentieth century - that is, until the "little brown man in the loincloth"16 entered the frame and burst the mythic bubble by the touch of his satyagraha - pure, nonviolent and persistent truth.

\footnotetext{
${ }^{15}$ Michael Rysbrack's chimney-piece was entitled 'Britannia receiving the riches of the East'. It took two years to complete, from 1728 to 1730. (Groseclose, 1995, pp. 49-50).

${ }^{16}$ A popular description of Mahatma Gandhi by his British contemporaries.
} 


\section{References}

Barthes, R. (1973). Mythologies. A. Lavers (Trans.). London: Paladin.

Barthes, R. (1974). S/Z, R. Miller (Trans.). New York: Noonday.

Barthes, R. (1977). Image music text. S. Heath (Trans.). London: Fontana Press.

Barthes, R. (1985). The grain of the voice: Interviews 1962-1980. L. Coverdale (Trans.). New York: Hill \& Wang.

Barthes, R. (1990). The fashion system. M. Ward and R. Howard (Trans.). Berkeley, CA: University of California Press.

Bremner, G. A. (2005), "Nation and Empire in the government architecture of midVictorian London: The foreign and India Office reconsidered." The Historical Journal, 48, 703-742.

Cavaliero, R. (2002). Strangers in the land: The rise and decline of the British Indian Empire. London: I. B. Tauris \& Co Ltd.

Chandler, D. (2007). Semiotics: The basics. New York, NY: Routledge.

Chomsky, N. (1993). Year 501: The conquest continues. Cambridge: South End Press.

Clairmonte, F. (1960). Economic liberalism and underdevelopment: Studies in the disintegration of an idea. New York, NY: Asia Publishing House.

Culler, J. (2002). Barthes - A very short introduction. Oxford: Oxford University Press.

Eco, U. (1994). Trattato di semiotica generale. Milano: Bompiani.

Fiske, J. \& Hartley, J. (1978). Reading television. London: Methuen.

Groseclose, B. (1995). British sculpture and the company raj. Church monuments and public statuary in Madras, Calcutta and Bombay to 1858. London: University of Delaware Press.

Halsall, P. (2000) "Bibliography on India and the Mediterranean." In Ancient History Sourcebook. Retrieved on 24-11-2015 from http://www.fordham.edu/HALSALL/ancient/mediterraneanandindiabib.html

Halsall, P. (1998). "Letter of the Emperor Jahangir to the King of England - 1617". In Indian History Sourcebook. Retrieved on 24-11-2015 from http://www.fordham.edu/halsall/india/1617englandindies.html

Harzinski, R. (2005). "A tale of two cloths: The transition from wool to cotton Undergarments in England during the Victorian age." Charleston, IL: Eastern Illinois University. Retrieved on 09-10-2015 from: http://www.eiu.edu/historia/Harzinski.pdf.

Hjelmslev, L. (1961). Prolegomena to a theory of language (Trans. F. J. Whitfield). Madison, WI: University of Wisconsin Press.

Hornblower, S. (1996). The Oxford classical dictionary. Oxford: Oxford University Press.

Jakobson, R. (1971). Selected writings, vol. 2. The Hague: Mouton.

Janin, H. (1999). The India-China opium trade in the nineteenth century. London: McFarland.

Keay, J. (1991). The honourable company: A history of the English East India Company. London: Macmillan Publishing Company.

Mukund, K. (1992). "Indian textile industry in the 17th and 18th century." In Economic and Political Weekly (September 19). p. 2058.

Nehru, J. (2004). The discovery of India. New Delhi: Penguin Books.

Robins, N. (2006). The corporation that changed the world: How the East India Company shaped the modern multinational. London: Pluto Press.

Robins, N. (2003). "Loot: In search of the East India Company". In Open Democracy, (22 January). Retrieved on 9-10-2015 from: http://www.opendemocracy.net/theme_7-corporations/article_904.jsp. 
Robinson, J. H., (1904-6). Readings in European history, vol. 2, From the opening of the protestant revolt to the present day, Boston, Ginn, pp. 333-35.

Saussure, F. de (1916/1974). Course in General Linguistics (trans.W. Baskin). London: Fontana/ Collins.

Slatyern, W. (2015). Life/death rhythms of capitalist regimes: Debt before dishonour, timetable of world dominance 1400 to 2100 AD. Singapore: Partridge Publishing Singapore.

Suchak, K. (1999). Rural industrialisation with special reference to 'Khadi'. Mumbai: Yogesh Suchak.

Thomas, P. J. (1963). Mercantilism and the East India trade. London. P. S. King \& Son.

Author address

Email: gonsalves.p@gmail.com

About the Author

Early this year, Peter Gonsalves published the last volume of his Gandhian trilogy entitled, Gandhi and the Popes, From Pius XI to Francis (Peter Lang, 2015). His two previous works are Clothing for Liberation, A Communication Analysis of Gandhi's Swadesh Revolution (Sage, 2010) and Khadi, Gandhi's Mega Symbol of Subversion (Sage, 2012). He teaches Media Education, Peace Communication, is in charge of the Doctoral Program and is Dean of the Faculty of the Sciences of Social Communication, at Salesian University, Rome. 